\title{
FAMILY METAPHORICS: A RHETORICAL TOOL IN THE EPISTLE OF 1 JOHN
}

\author{
Dirk G. Van Der Merwe
}

University of South Africa

\begin{abstract}
This article examines how the author of the First Epistle of John uses family metaphorics rhetorically to convince his adherents of their identity as Christians, and to persuade them towards certain conduct in relation to their identity. $\mathrm{He}$ employs a network of metaphors to describe the character of this community life, which was familiar to the people of the first century Mediterranean world. These metaphors have been used in conjunction with various rhetorical devices. This article commences with a discussion of what family metaphorics is, followed by a discussion of the use of familial images in rhetoric. The gist of the article concerns an application of "family dynamics" in the discourse of "metaphor" and "rhetoric".
\end{abstract}

\section{Introduction}

When reading 1 John the reader becomes aware of the author's (hereinafter referred to as "the elder") frequent use of kinship language and household relations. This actually dominated the descriptions of, and prescriptions for, the church in the New Testament. The family concept, as a primary social structure, has been used by some New Testament authors metaphorically to reflect on the relationship between God and the early Christians. Kinship, especially spiritual kinship, is perceived as representation and reflection of identity and pragmatic values. Yet, there is a growing awareness that a single model or concept of "family" obtains no more for antiquity than it does for contemporary life. The choice to refer to "families" (plural) rather than "family" (singular) life in antiquity is to admit plurality at the expense of comforting generalisations. Bearing in mind this plurality, this article attempts to reveal how the elder succeeds in using the most basic characteristics of family life to reflect on the relationship between God and His worshippers or, more particularly, God and the adherents of the elder. 
A further objective is to point out from a socio-rhetorical perspective how the elder has used the family concept metaphorically and especially rhetorically in 1 John to guide his adherents in their understanding of their identity and conduct in the Christian religion. Therefore, this research will start by examining The family as metaphor, followed by a discussion of The familial image in rhetoric, and ending in a merging of these investigations in Family dynamics in the familia Dei.

\section{The Family as Metaphor}

\subsection{What is a Metaphor?}

When reading 1 John it becomes apparent how the elder uses family metaphorics to describe how the members in the Johannine community should live as Christians. According to Rosenblatt (1994:1) a metaphor is "a figure of speech in which words that literally denote one kind of object or idea are used in place of another, suggesting a resemblance or analogue". As Lakoff and Johnson (1980:3) noted, "Metaphor is pervasive in everyday life, not just in language but in thought and action." They also state that "[t]he essence of metaphor is understanding and experiencing one kind of thing in terms of another" (Lakoff \& Johnson (1980:5). Metaphorical language forms an important part of any culture (Lassen 1997:103). Its main function is "to provide a partial understanding of one kind of experience in terms of another kind of experience" (Lakoff \& Johnson 1980:154). As a result of this truth, much of human understanding of the world is constructed by metaphors (Schroots, Birren \& Kenyon 1991:2). A metaphor can help to create new meanings and new perspectives; it is a way of taking what we know and applying it to an area that is less understood. Metaphors can enable us to understand human behaviour and to explain feelings. "Metaphors always involve the highlighting of certain aspects of phenomena and the obscuring of others" (Schroots et al. 1991:3).

At an individual level, metaphors are used to describe the unknown in terms of the known. This implies that metaphor is used to construct meaning. At a communal level, metaphors are used for a wide variety of social purposes. In theological writings, these two functions of metaphor frequently converge. On the one hand, metaphor is used to describe that which is by definition unknowable, the divine. On the other hand, it describes how members, associated with one another, have to behave towards one another (cf. Brettler 1989).

This figure of speech will now be investigated with regard to the use of the family concept as metaphor in early Christianity.

\subsection{The Metaphor of Family}

The teaching of 1 John is group teaching. This is in line with the ancient Mediterranean worldview: it is the group that is important, ${ }^{1}$ not so much the individual. Individual behaviour is constituted and regulated by the community or the group to which such a 
person belongs. Such behaviour is focused on their wellbeing. Neither the individual nor any outsider determines the behaviour in the group. In the symbolic narrative created by the elder, such group orientation (koinwnia, 1:3, 6f) constitutes the sociohistorical structural core (cf. Van der Watt 1999:148ff). ${ }^{2}$ The in-group of the Johannine community, and how the common life is lived within this group, is what matters to the elder, and this is the focus of his doctrine and ethics (cf. Botha 2005:395-6).

To describe this existential reality of being and living as a Christian in such a group, the elder uses the most intimate social phenomenon in the ancient world, namely "the family" (Van der Watt 1999:494). ${ }^{3}$ Hence, the language used for referring to the adherents of the elder is strikingly familial. The elder defines and describes the kind of fellowship that should be constituted, and should exist in this Christian community, by applying the best of what he knows about earthly families to the relationship between true believers communally and between these believers corporately with God (cf. Tollefson 1999:85). The familia Dei then is the sphere in which this fellowship is constituted and experienced.

By reminding his adherents of their fictive kinship, ${ }^{4}$ of their common identity, ${ }^{5}$ and the values, conduct and doctrine that set them apart from other groups (the deceivers) in their society, the elder entrenches their identity as a group, and serves to continue to regulate social (ethical) behaviour in this group. This injunction by the elder and his paraenesis serve to strengthen their identity and unity in a world which seems somewhat hostile towards them. The community is reminded by the elder not to let the outside world stain them. Thus, to achieve this, the elder portrays their character and way of living to be like that of members of God's family (familia Dei).

When reading 1 John it becomes apparent how the elder uses a coherent network of metaphors, ${ }^{6}$ related to the social reality of first century family life (Van der Watt 1999:491; Lassen 1997:103; Moxnes 1997), to explain fundamental Christian concepts. The elder incorporated widely accepted conventions from everyday family life and applied them to what happens in the community. He uses generally accepted ideas on family life to explain what the Christian life in the community comprises. ${ }^{7}$ Through doing this he rhetorically tries to activate the social dynamic of the interrelatedness between a father and his child in the mind of the first-century reader.

Fortunately the images referring to certain social aspects are developed in the text itself. Only where external social information is helpful to supply reference material will it be consulted to help describe some of the social conventions of ancient times. But, before any investigation regarding "family dynamics" in 1 John can be conducted, the use of "familial image in rhetoric" needs to be discussed.

\section{The Familial Image in Rhetoric}

This subsection indicates how the family image can be used as a rhetorical device. Osborn (1967:115), in his research on "archetypal metaphor in rhetoric" opens up important new lines of rhetorical analysis. His view of archetypal metaphor "carries 
the idea of basic, unchanging patterns of experience". Osborn (1967:116) claims that archetypal metaphors exhibit a persuasive potency because of their attachment to basic motives:

Because of certain universalities of appeal provided by their attachment to basic commonly shared motives, the speaker can expect such metaphors to touch the greater part of his audience. Arising from fundamental interests of men, they in turn activate basic motivational energies within audiences, and if successful, turn such energies into powerful currents running in favour of the speaker's recommendations.

In his study Osborn focuses mostly on "naturalistic" archetypes and the metaphoric force they generate. The metaphoric images that Osborn worked on all derive their persuasive power from the power of the natural physical forces they invoke by comparison to significant social situations (see also Adams 1983:56). ${ }^{8}$

In this article the focus falls on the "family image" as archetype. ${ }^{9}$ The family is a relational image which gathers its archetypal "force" from the time and traditions surrounding the cultural construct "family". The "family" seems to be one of the oldest and most primary entities of social cohesion. It reaches back to the beginning of civilisation. Human beings have been united in the family experience for as long as human existence. The role of family members carries with it deep persuasive implications as a motive term. Hence, familial images derived from a "common place and literal associations between human beings. They are the simple states of familial relatedness that we pass through as members of the social matrix, where, conjoinment with others is the source of procreation and culture, and the creative grounding of our existence. To be related in family is the archetypal emphasis of humanity" (Adams 1983:56).

Thus, just as "naturalistic" metaphors have an impact upon people, so do relational images have an impact and act to unify people. Family bonds are made explicit by the elder in his use of selected words, analogies or comparisons that denote or connote familial states among his readers. The use of relational images entangles the elder and his adherents in relationships that have a priori behavioural expectations built into them. This suggests that familial images in written communications can be effective in evoking primary "actions, attitudes, and emotions". By using familial terms, the elder involves personal cognitive and emotional attachments that exist in early life within the extended family and should apply within the koinwnia of believers. These expectations are stored in the archetypal relational pattern as it has been played out through centuries of human situations. The concept "son", for example, entails certain generalisable rights, duties, privileges, attitudes, pitfalls, problems, etc, which are associated with it. These associations can set up expectations, attitudes, emotions and actions if the adherents of the elder can be made to feel "son-ish". The same applies for the figure of the "father" and "life in the family" (Adams 1983:56).

When the elder tries to get his adherents imaginatively bonded-in-family, he exhibits a collective orientation. This is important because much discourse is designed to bond people for collective efforts and/or distinguish them from other different groups. In such 
an experience the elder has at his disposal a range (or network) of familial images that can be conjured for collective purposes. It is the familial entanglement of his adherents that brings about a unity of purpose spelled out by the cultural or religious norms surrounding the particular relationship. In this sense relational images have a "bonding power" that differs from other references of categorisation. For example, the category "brothers and sisters" is a much more powerful reference for unification than "people" because "people" lacks the familial connotation and potency (Adams 1983:56f).

This explanation convincingly highlights the strong rhetorical dynamic of the family metaphor. When it is applied in a specific situation to a certain group of people it generates bonding powers which unite these people into a coherent group.

This brings us to the point where we reflect on "the familia Dei in 1 John" with regard to using family metaphorics rhetorically.

\section{$4 \quad$ Family Dynamics in the Familia Dei}

We now consider how the elder constructed this new family to promote perseverance in the family of faith and adapted the ethics of kinship of the new community. Bearing in mind that a network of metaphors which relate to family life has been used to discuss identity and ethical matters in the socio-historical structure of the first-century C.E., the relevant social conventions of that time have to be considered for better understanding. In using these complex metaphors, the elder only focuses on certain central and widely accepted aspects (Van der Watt 1992:272-9) relevant and important for his purpose. It is significant to explore how the elder uses them.

The elder portrays the Christian life of fellowship ${ }^{10}$ in the Johannine community as existence in a family (Rusam 1993:105ff; Van der Watt 1999:494ff; Van der Merwe 2005:443f), ${ }^{11}$ the familia Dei, ${ }^{12}$ where God is the Father (ton patera, 3:1,) and the head. The believers are "children of God" (tekna qeou, 3:1-2, 10; 5:2), "born from God" (gegennhmeno" ek tou qeou, 2:29; 3:9; 4:7; 5:1, 4, 18). They confess that God is "Father" (pathr, 1:2; 2:1, 14-15, 22-24; 3:1; 2 John 4) and are referred to by the elder as "brothers" (adel foi and sisters, 3:13) to each other. ${ }^{13}$ The Father gives the believers "eternal life" enabling them to partake in this new family $(2: 25 ; 3: 14-15 ; 5: 11-13)$. Jesus is the only (monogenh,4:9, "Son" of the Father (EIhsou" estin o uio" tou qeou, $4: 15$ ), to whom the newborn children of the Father must adapt their lives. The Holy Spirit is the Spirit of God (to pneuma tou qeou, 4:2f), which constitutes the presence of the Father $(4: 13 ; 3: 24)$ and guides and educates His children $(2: 27)$ in the familia $D e i$. By doing this the elder brings the Father, Jesus, the Holy Spirit and believers into fellowship like that of an extended earthly family (cf. Tollefson 1999:88). To become a member of this, one has to be born into this family. The metaphorical and rhetorical function of this "new birth" will now be addressed. 


\subsection{New Birth as Entry into the Familia Dei}

1 John, like the Gospel (John 3:3), speaks of entry into the family of God as a new birth, being begotten by God, having the seed of God implanted in His child's inner being (ex autou (qeou) gegennhtai, 2:29; 3:9; 4:7; 5:1, 4, 18). Here the elder uses language commonly used when speaking of family life to express Christian truths. Thus, to become a member of the familia Dei, a person has to be born into it, according to the elder. This happens through faith ${ }^{14}$ in Jesus Christ, the (monogenh, 4:9) Son of God $(4: 15 ; 5: 5)$.

In 2:29 the elder probably preferred to use the phrase ex autou ${ }^{15}$ gegennhtai by way of introduction to the subsequent section where the theme tekna qeou is introduced. ${ }^{16}$ In this context it seems as if the expression ex autou gegennhtai in 2:29 expresses a close and intimate relationship that relates to "we walk in the light" (en tw fwti peripatwmen, 1:7). Used metaphorically, the verb gennaw serves to indicate the beginning of a relationship or just a relationship that is comparable to a family relationship, in other words that between a parent and his/her child. Through their rebirth God's children enter into a new relationship; they become His children $(3: 1,2$, $10 ; 5: 2) .{ }^{17}$ However, in the new birth and the implanting of the divine seed, the elder clearly sees something more than a new relationship. According to Ladd (1998:664) it means that a new dynamic, a new power, has entered the human personality, which is confirmed by a change of conduct. For the elder, the highest claim these believers could make for their lives is to claim fellowship with God. This implies that they have come to the point where they can start to know the character of God (John 17:3), which has become the transforming reality in their lives..$^{18}$ According to the elder the child of God has found a new orientation of his will - and has to live according to the will of God, to love and obey Him, to break with sin and to follow the path of righteousness. ${ }^{19}$

\subsection{The Members in the Family}

In this brief discussion it will become apparent that the Father is the patriarchal head of this family and his children must be obedient to Him, and live according to His character. It will now be discussed how the different constituents of the family each have a rhetorical function to accomplish this.

\subsubsection{The position and function of the Father ${ }^{20}$}

In 1 John God is depicted as the Father $(1: 2,3 ; 2: 14,15,22-25 ; 3: 1)$, as the paterfamilias. From a partriarchal perspective $\mathrm{He}$ is depicted as the head of the family. The nature of the Father determines the new status and rules of conduct to which His newborn children have to conform. The elder characterises Him to be light (o qeo" fw" estin, 1:5), righteous ([o qeo"] dikaio" estin, 2:29) and love (o qeo" agaph estin, 4:8, 16). ${ }^{21}$ As the one who cannot be seen $(4: 12,20)$, He is the One who is in command. He knows everything $(3: 20)$. He creates koinwnia, enabling them to be part of this new 
family $(2: 25 ; 3: 14-15 ; 5: 11-13)$. He gives eternal life through his Son $(1: 2,4: 9 ;$ cf. also $4: 11,14)$. God lives with and in His children by way of the Spirit (3:24). The Father takes care of His family through His Spirit. Therefore, His children have to take on His character.

\subsubsection{The position and function of the Son}

Jesus is depicted as the Son of God ( $3: 8 ; 4: 15 ; 5: 5,10,12,13,20 ; 2$ John 3$)$. Jesus is eternal life personified $(1: 1-2)$. He is without $\sin (3: 5)$. He is also referred to in functional terms (Van der Watt 1999:502) in relation to God's children: therefore through him (his blood) people are cleansed from all sin (1:7). He is the believer's atoning sacrifice (ilasmo , 2:2) and advocate (paraklhto , 2:1) by the Father. He is righteous (EIhsoun Criston dikaion, 2:1). He is pure (ekeino" agno" estin, 3:3). As the truth (5:20), he reveals $(1: 1)$ in order to give understanding $(5: 20)$. He restores broken koinwnia. He gives God's children understanding to know Him who is true $(5: 20)$. Therefore, the children of God have to believe in the Son and follow him. They are commanded by the elder, in his usage of the emphatic subordinating comparative particle kaqw juxtaposed to the adverb outw $\sim$, to live as Jesus lived: kaqw ekeino periepathsen kai auto [outw ] peripatein.

\subsubsection{The position and function of the Spirit}

According to the elder, this new existence of the believer as an existence in the familia Dei can be experienced in a concrete way by the Holy Spirit who applies to God's children the redemptive work of the Father and the Son (2:20). The chief functions of the Spirit are those of illuminator (2:20), teacher (2:27), empowerer (3:24 in the context of obedience; 4:13, in the context of love), ${ }^{22}$ confessor (4:2) and witness (5:7f) (cf. Kenney 2000a:47). The Spirit becomes the guiding influence in the lives of God's children $(2: 20-7 ; 5: 7)$, influencing their conduct. It is the Spirit that influences and leads these children to act right (dikaio" - 2:29; 3:7, 12; cf. also 3:10), to walk just as Jesus walked (2:6). The Spirit will give God's children knowledge (oidate - 2:20). The Spirit witnesses to this truth (5:6a) and will guide these children in the truth $(5: 6)$ (see also Von Wahlde 1990:126ff). The purpose of the multiple references to the work by the elder is to convince the readers that they, as children of God, have no excuse not to become Father-like.

\subsubsection{The position and function of the children of God}

The adherents of the elder were depicted as "the children of God" $(3: 1,2,10)$. They are also born of God $(2: 29 ; 3: 9 ; 4: 7 ; 5: 1,18)$ and in $3: 9$ it is said that "God's seed" abides in them. The community of mutual love is none other than an expression of a mutual abiding (menein $)^{23}$ with God the Father. God's children abide in Him and He in them $(3: 24 ; 4: 13,16)$. They know the Father and do what pleases Him $(3: 22) .{ }^{24}$ When they 
became part of the familia Dei, major fundamental changes took place in their lives. The picture of these changes is derived from an analysis of their status and the change in their social behaviour, as depicted by the elder, and has both individual and corporative implications. The new status and rules of conduct to which the children of God have to conform are determined by the head of this family, the Father of the family. ${ }^{25}$ According to the elder, these attributes of God the Father must be recognised and imitated (2:6) by God's children.

This metaphor is further strengthened by the elder when he refers to his adherents as "(little) children or children of God"26 or also in terms of "brothers"27 (also the frequent occurrence of the preposition with the pronoun met all $\mathrm{hl} \mathrm{wn}^{28}$ - with one another).

In conclusion it can be said that in using the family metaphor the elder tried to strengthen "familial associations" to rhetorically express and bring about "familial responsibilities and conduct". Such familial responsibilities and conduct are expressed by the elder in terms of "life as existence in the family".

\subsection{Life as Existence in the Family}

\subsubsection{The quality of life}

The elder uses the phrase "eternal life" to spell out the existence in the familia Dei. This life, which has been personified in Jesus, is spelled out in terms of fellowship which has been created by an imitatio Christi which again is an imitatio Dei. Seeing that the believer has been born into this family (ex autou gegennhtai) and has to take on the "same life" as the Father, a certain conduct in relation to the believer's nature is expected. On the one side it must be a conduct that will not harm (amartia) the fellowship, while on the other side it must be a conduct that will strengthen the fellowship. ${ }^{29}$

The obedience of members is determined by their group adherence. If such group adherence and its corollaries are negated, the respective narrative structures will collapse. In 3:11-18 a deceitful brother's (Cain) anti-group behaviour is explained and denounced. This behaviour shows that such a person does not belong to the family, since members of the family are urged by the elder to care for one another (3:16f) and will certainly not harm one another. Family cohesiveness and corresponding loyalty will be manifested through "right" behaviour towards one another (3:10). In 1:6-2:2 the elder describes the problem of violating the conventions of such a family (group). If such a wrongdoer (amartia) still claims to be a member of that particular family, confession is required (1:9), so that the relations within the family can be restored. The Father deals with such matters in cooperation with the paraklhto who acts on behalf of the family $(2: 1-2) .{ }^{30}$

The elder explains how this new existence can be experienced in a concrete way. God now lives with and in His children through the Spirit (3:24). The Father takes care of His family through His Spirit. One should be cautious not to confuse all spiritual experiences as coming from the Spirit of God (4:1-2). 


\subsubsection{Living in the family - a matter of koinwnia ${ }^{31}$}

Life in this family is a matter of having fellowship (koinwnia). Mutual fellowship among one another, and corporately fellowship with God the Father, constitute the character of existence in this family. 1 John 1:3-4 describes how a person is invited into koinwnia with other members of the family (meq hmwn) and the Father and his monogenh (4:9) Son. The noun koinwnia is a significant theological term in $1 \mathrm{John}^{32}$ which occurs twice in the prooemium (1:3bis) and two more times in the rest of chapter one $(1: 6,7)$ to create a rhetorical chiastic pattern.
A ina kai umei" koinwnian echte meq hmwn (1:3)
B kai h koinwnia de h hmetera ...meta tou patro" kai meta tou uiou autou Ihsou Cristou (1:3)

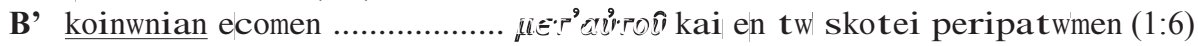
$\mathbf{A}^{\prime}$ ean de en tw fwti peripatwmen w" auto" estin en tw fwti, koinwnian ecomen

met allhlwn (1:7)

The function of the chiastic structure is to emphasise the interrelatedness and interdependency of the mutual fellowship among believers and their corporate fellowship with God, the Father. The one kind of fellowship demands and constitutes the other. According to Danker (2000:552), the Greek word koinwnia lexicographically means "close association involving mutual interests and sharing, association, communion, fellowship, close relationship". The semantic meaning, according to Louw and Nida (1988:446), relates to Danker's definition: "an association involving close mutual relations and involvement - "close association, fellowship.". ${ }^{33}$

Founded on the above related definitions and based on the adjective meaning "common" (koino ), the noun koinwnia then denotes the active participation or sharing in what one has in common with others: doing something together or sharing something (Haas, De Jonge \& Swellengrebel 1972:27). The nature of what is mutually shared moulds the character of the group. In this context it refers to the "new life" (cf. 1:1, 2; $2: 25 ; 5: 11-13)$ that the believers share with Christ and with one another. This "new life" in Christ, according to the elder, creates and stimulates the desire for such fellowship and calls not for isolation, but for active participation with other believers in this "new life". This horizontal fellowship is essential for true vertical fellowship. The elder makes the rhetorical reference of "we have fellowship with one another" (koinwnian ecomen met allhlwn, 1:7) and this is dependent on "you may have fellowship with us" (koinwnian echte meq hmwn, 1:3) which opens up koinwnia with the Father and his Son Jesus Christ (cf. Painter 2002:128; Rusam 1993:182; Westcott 1982:11). Both these aspects reflect, influence and constitute the other and occur throughout the epistle in other formulas and concepts.

The elder wants to emphasise that this family is a spiritual family ${ }^{34}$ that supercedes, existentially and ethically, the physical family to which a person belongs. According to him a person lives spiritually while still living on earth. This implies that a person exists 
in a different mode of being on earth - already possessing this eternal life. This means membership of another (spiritual) family. Supreme loyalty is owed to this spiritual family. By accepting this new way of life, new rules and new values replace previous traditions, rules and values.

Throughout the epistle this fellowship is also described in terms of "formulas of immanence" and "antithetical parallelisms". These two modes of expression will now be investigated.

a) Koinwnia as a matter of "knowing", "having", "to be in" and "abiding in" God

These rhetorical formulas of immanence (Immanenzformeln) (Schnackenburg 1992:63f) describe the qualitative lifestyle of believers. All these formulas of immanence show the central significance of this concept in 1 John, which has a strong connection with other leading concepts, especially that of a "child of God" (3:1-3) which has strong ethical implications (cf. Lieu 1991:42). It points out that the elder expresses believers' fellowship (koinwnia) with God in various ways as "knowing", "having", "to be in" $(2: 5 ; 5: 20)$ and "abiding in" $(2: 6,24 ; 3: 24 ; 4: 13,15,16)$ God.

Seen from the perspective of family imagery these formulas of immanence point basically to a "qualitative and functional union on the basis of shared status, conviction and custom as members of the same family" (Van der Watt 1999:503); they influence one another to think and act alike.

b) Koinwnia a matter of Imitatio Christi: “...ought to walk just as he (Jesus) walked” $(2: 6)^{35}$

Throughout the epistle the elder emphasises that the children of God should act according to their status and knowledge. ${ }^{36}$ The behaviour of God's children has to relate to the social behaviour (rules and values) of the family into which they are born. "Family life" implies specific ethical conduct. Therefore, the elder insists upon a correspondence between internal state and external behaviour.

The elder uses the verb peripatein ${ }^{37}$ (translated as "walk" or "live") rhetorically to describe the conduct in the familia Dei. The five times he has used it in $1 \mathrm{John}$ were in connection with "having fellowship" with God $(1: 6,7 ; 2: 11)$ and "imitating" Christ (2:6). For "living" in the light the elder suggests actions that correspond to the Father's actions (cf. Schnackenburg 1967:312). In 2:6 he states that the lifestyle of believers should correspond with that of Jesus: kaqw" ekeino" periepathsen kai auto" "outw"1/4 peripatein. This is a matter of deliberative rhetoric because the elder, knowing which ethical conduct is recognised as superior to others, tries to persuade his adherents to follow a particular course of action.

According to the elder Christ is the template for the conduct of believers, because Jesus' way of life was analogous with the character of the Father. Therefore, the elder has pointed out that ethics in 1 John is not a matter of a set of rules; it is an existential way of living that is established by the attitude and behaviour of Jesus, the Son of God. This "way of living" can only actualise in believers through the Spirit. ${ }^{38}$ Through the 
existential guidance of Jesus and the spiritual guidance of the Spirit the believer finds his/her way as a child of God to please the Father (3:22).

A comparison of Christian behaviour with the life of Jesus is part of the elder's rhetoric to motivate God's children to live in the familia Dei as Jesus did. ${ }^{39}$ All this is a matter of doing the will of God the Father (2:17). Ethics in the familia Dei is determined by what the Father of the family requires. Therefore, the conduct of all the members of the family should reflect the character of the family as it is personified in the head of the family (cf. Van der Watt 1999:506).

Now, for the elder to convince his readers to believe this and consequently to embrace this conduct, the text of 1 John includes dualistic concepts and anti-language which he spells out in terms of dialectic discourse. Dialectic discourse is defined as one kind of rhetorical technique that makes extensive use of antithetical and binary language to persuade or convince others of the element of truth or correctness of one's position that would otherwise be difficult to obtain. ${ }^{40}$ Structure in dialectical discourse is generated internally step by step by way of explanation and intellectual enlightenment, in the flow of thought as the author moves from one theme to another and then returns to former themes to add new data. ${ }^{41}$

Dialectical discourse makes special use of metaphors referring to transformation or "becoming" to persuade the reader that change is not only possible, but inevitable (Murphy 1971:116). In the case of 1 John, each new dialectical choice becomes an opportunity to guide the reader in the selection of those decisions in life which give a measure of right conduct regarding the ethics of the familia Dei. This way of life, according to the elder, comprises to love against to hate, to live a life of righteousness against a life of unrighteousness and to live in the light against to live in darkness. ${ }^{42}$

\section{Conclusion}

The elder, conjoined with other New Testament authors, compares the relationship between God and the Johannine community in terms of a family relationship. He describes it from the perspective of ancient Mediterranean family life with adaptation to the lebensraum of the familia Dei. He uses the family metaphor in such a way to convince the community about their identity and consequently the conduct expected of them in this relationship. Actually a network of metaphors has been used by the elder to describe the character of this family life, which was familiar to the people of the first century Mediterranean world.

These metaphors have been used in conjunction with various rhetorical devices to convince the community regarding their identity in God and their conduct towards God and in this world. The rhetorical devices that have been used by the elder are as follows:

1. Archetypal force: The family is a relational image which gathers its archetypal "force" from the time and traditions surrounding the cultural construct "family". The "family", as one of the oldest and most primary units of social cohesion, 
reaches back into the dawn of civilisation. Human beings have shared in the family experience for as long as human existence. The network of metaphors used sets up associations of expectations, attitudes, emotions and actions regarding family relationships and responsibilities. Within this rhetorical device, other devices are embedded to complement and to strengthen the elder's argument regarding this relationship.

2. The patriarchal Father figure: The position and image of the Father is patriarchal and prescriptive. He is the head of the family. He prescribes the way of living in the family. Because He has been depicted as "light", "righteous" and "love" it has been expected of His "children" to live according to His character. His character determines the identity and conduct of the family members.

3. Familial associations: The elder refers continuously to his adherents as "children of God" and "brothers." The uses of relational images entangle the elder and his adherents in relationships that have a priori behavioural expectations built into them. This point is enforced by the elder in his references to how to become part of such a family. An obligation is placed on a new member to take on the conduct of this group due to a new orientation that has taken place in such a person, which the elder describes in terms of a "new birth in to a new family".

4. Tightening of group adherence: By referring to the community as the "children (family) of God": At the point where a community becomes imaginatively bondedin-family, it exhibits a collective orientation. For such an experience the elder has used a range of familial images for collective purposes. Relational imagery is conjured by the elder in order to entangle his readers (adherents) in family unity and fellowship. Relational images are used to provide powerful bases of motivation that act to bind his adherents together by arousing in them a familial orientation.

5. Son of God imitation - deliberative rhetoric: The elder, knowing which ethical conduct is recognised as superior to others, tries to persuade his adherents to follow a particular course of action. The elder links the Son of God with the characteristics of the Father. Therefore, the "children of God" are also called to live as Jesus lived. Thus, the call for the imitation of the Father is strengthened by the imperative to imitate Jesus. This is complemented by rhetorical formulas of immanence which the elder uses to command the children of God to perform.

6. Antithetical parallelisms: Family life has been described in terms of antithetical parallelisms: love as opposed to hate; light as opposed to darkness; abide in as opposed to not abide in; to confess that Jesus is the Christ as opposed to not to confess that Jesus is the Christ.

The most amazing thing about these various rhetorical devices is that they are not used alongside one another, but are closely interwoven with one another and some are even embedded in each other. The elder mastered this skilfully. 


\section{NOTES}

1 In his study of first-century Mediterranean persons, Malina (1996:64) concluded that these people were strongly group-embedded, collectivistic persons. Therefore, they were socially minded, and attuned to the values, attitudes and beliefs of their in-group. Hence, their conduct was controlled by strong social inhibitions. Personal inhibition in general lacked. Their prevailing social institution was kinship; familism was foremost in people's minds. In such a group, recognised principles with common interests and rules (norms), fixing rites and duties of the members in relation to one another and to these interests exist (Robbins 1996:101).

In the New Testament, Jesus groups are also described from a strongly "group-embedded, dyadic, collectivistic perspective", conceiving of themselves as forming "the household of God" (familia Dei). Sandnes (1997:156) points out that "in the family terms of the New Testament, old and new structures come together. There is a convergence of household and brotherhood structures. The New Testament bears evidence of the process by which new structures emerged from within the household structures. What we see in the New Testament is not an egalitarian community that is being replaced by patriarchal structures; the brotherhood-like nature of the Christian fellowship is in the making, embedded in household structures." To have a proper understanding of the family metaphors involved, it is necessary to bring together questions about what the documents say and questions about the historical and social contexts of these documents (Sandnes 1997:156).

2 The understanding of the characterisation of the Johannine community relates closely to Robbins' (1996:101) definition of a corporate group: "A corporate group is a body with a permanent existence: a collection of people recruited on recognized principles, with common interests and rules (norms), fixing rights and duties of the members in relation to one another and to these interests."

3 According to Berger and Luckmann (1966:120), part of the function of paraenetic utterances is social formation, where admonitions are made to strengthen the induction "of an individual into the objective world of a society or sector of it". This is exactly what the elder is doing; he is reminding his adherents of the shared common values of their particular group that set them apart from the group of deceivers.

4 Malina (1982, 1986, 1993) and Esler (2000:147) have pointed out how important group identity, real kinship and fictive kinship relations were in the first century Mediterranean world - they fully determined the identities of individuals. In postmodern Western societies, kinship does not really play such an important institutional or structural role, but in antiquity it was a different ball game. Then kinship was one of the primary ways of structuring social life. In postmodern Western society, one can belong to many groups at the same time without experiencing any conflicts. In antiquity it was different. Because the social order was dominated by group/kinship allegiances, membership or alliance with another group was not permitted. A member of a particular kinship or fictive kinship group could not show any allegiance to any other group (Ean eipwmen ..., 1:6, 8, 10; o legwn ..., 2:4, 6, 9; ean ti" eiph ..., 4:20).

5 See adelfoi [2:9, 10; 3:10, 12(bis), 13, 15, 17; 4:20(bis), 21; 5:16], allhlou" [1:7; 3:11, 14, 16, $23 ; 4: 7,11,12 ; 2$ John 5].

6 Metaphorical language forms an important part of any culture (Lassen 1997:103). Its main function is to "provide a partial understanding of one kind of experience in terms of another kind of experience" (Lakoff \& Johnson 1980:154). 
7 Achtemeier, Green and Thompson (2001:547) assert that the family imagery may provide useful evidence regarding the internal structure and organisation of the Johannine community. This implies that the Johannine community would have understood exactly what the elder was trying to communicate.

8 Osborn (1967:117) indicates that "light relates to the fundamental struggle for survival and development because of its relationship to warmth, sight, growth, etc". The antithesis of light is darkness. If a rhetor can metaphorically relate "light" associations to certain people or propositions, and in turn relate "dark" associations to opponents or opposing arguments, then the rhetor can effectively arouse feelings that are generally related to the "image" of the fundamental struggle between life and death symbolised by light and darkness. In such a way, according to Osborn, the rhetor can deepen the urgency of the situation and magnify the importance of a conflict. The symbolic triumph of life (light) over death (darkness) deepens the sense of satisfaction and commitment towards the decision. The same applies to the connotation and denotation of light to "what is good" and darkness to "what is evil", two metaphors also used in 1 John by the elder.

9 On this archetype of "family" I rely strongly on the work done by Adams.

10 Alongside "to have fellowship with God", which is only found in 1:3 and 6, one of the most common phrases is "to be in God" (oti en autw esmen, 2:5; 5:20) or "to abide" (menein, 2:6, $24 ; 3: 24 ; 4: 13,15,16)$. This combination with the typical word menein is usually expanded (except in 2:6, 24) into a twofold or reciprocal formula ("we in God and God in us") or vice versa. Another expression of fellowship with God found only in 1 and 2 John is "to have the Father" (ton patera ecei) or "the Son" (o ecwn ton uion, 1 John 2:23; 5:12; 2 John 9). "To know the Father" (egnwkate ton patera) comes down to the same thing (2:3 [cf. 2:5]; 2:13, 14 [cf. 1:3]). Believers are also indicated to be "of God" (estin ek tou qeou, 3:10; 4:4, 6; 5:18f). God also abides in believers through His Spirit that He has given them (menei en hmin, ek tou pneumato" ou hmin edwken, 2:3; 3:24). See also Lieu 1991:31-48; Schnackenburg, 1984.

11 Esler (2000:148) points out that neither in Greek nor in Latin was there even a word that corresponded to our word "family", although oiko in Greek and domus in Latin refer to the house and the household. This concept also occurs in Galatians and 1 Thessalonians in the New Testament (Esler 1997:121ff; 2000:145ff).

12 In the Old Testament the term "bêth" or "house", like the word "family" in modern languages, is flexible and may even include the entire nation ("house of Jacob" or the "house of Israel"), or a considerable section of the people (the "house of Joseph" or the "house of Judah"). It may denote kinship in the wide sense (De Vaux 1973:20).

13 The elder also repeatedly addresses his flock as "little children" (teknia, 2:1, 12, 28; 3:7), and "beloved" (agaphtoi, 2:7; 3:2, 21; 4:1, 7, 11; cf. 3 John 1, 2, 5, 11).

14 Another way of expressing the same truth is to speak of pisteuwn ei" ton uion tou qeou (5:10), o ecwn ton uion (5:12), even as the Gospel (1:12) speaks of elabon auton (Jesus).

15 In all the other occurrences $(3: 9 ; 4: 7 ; 5: 1,4,18)$ the pronoun auto is substituted by qeo . According to Haas, De Jonge and Swellengrebel (1972:75) the pronoun here refers to God, as is clear from the next verse.

16 When the elder addresses his readers as "children" he uses different words - "teknia" $(2: 1,12$, $28 ; 3: 7,18 ; 4: 4 ; 5: 21)$ and paidia $(2: 14,18)$. In contrast 2 and 3 John use only tekna (2 John 1 , 4,$13 ; 3$ John 4 ) for the community. 
17 Paul sees believers as children of God, but by adoption rather than by new birth (Rom 8:15).

18 In this epistle, the picture of these children (adherents of the elder) is clearly contrasted with a similarly developed picture of those ek tou kosmou (opponents of the elder). In the elder's comparison of the believers with the world, they become aware of the existential differences concerning status and behaviour between them and the world.

19 In 2:29 the phrase ex autou gegennhtai is linked with the phrase poiwn thn dikaiosunhn. "To do right", or "to do what is right", is used here (and in 3:7,10) in the sense of imitating Christ, who did what is right. This can also be compared with "walking in the light". Dikaiosunhn is what is in accordance with the will of God. Thus pa" o poiwn thn dikaiosunhn is the proof that ex autou gegennhtai (2:29).

The same thought is expressed negatively in 3:9 and 5:18: Pa" o gegennhmeno" ek tou qeou amartian ou poiei, and positively in $5: 4$, where the consequence mentioned is nika ton kosmon. In other passages (cf. 2:29; 4:7; 5:1) the child's behaviour is viewed not as the consequence, but as the proof of his/her being born of God. This concept is more explicitly defined in chapter 3. Still under the influence of the story of Cain (3:12), "not to be of God" is reciprocally formulated as "to be of the devil" (3:8) or "of the evil one" (3:12). There are spirits that are of God and others that are not. The spirits not of God are tou anticristou (4:3) or to pneuma th" planh" (4:6). The parallelism here suggests a real symmetry between being of God and being of the devil (Lieu 1991:39).

20 According to De Vaux (1973:20) the father had absolute authority over his children, even over his married sons if they lived with him, and over their wives. In early times this authority included even the power over life and death.

21 According to Culpepper (1995:142) believers' "fellowship with God" is constituted, in the light, in truth, in righteousness, and in love - which he calls metaphors for God's nature. He adds the noun $\mathrm{h}$ alhqeia (5:6) where the elder refers to "the Spirit is the truth" (pneuma estin $\mathrm{h}$ alhqeia).

22 Kenney (2000a:47) points out that $1 \mathrm{John}$ awards equal importance to the three themes of obedience $(1: 5-2: 6 ; 2: 29-3 ; 10 ; 5: 13-21)$, love $(2: 7-11 ; 3 ; 11-18 ; 4: 7-21)$, and belief $(2: 18-28$; $4: 1-3 ; 5: 5-12)$.

23 The verb menein is used 117 times in the New Testament. Over half the uses occur in the Johannine writings in connection with God's word (2:14, 24bis), seed (sperma, 3:9), anointing (crisma, 2:27), the Spirit (3:24; 4:13), God's love (3:17), God self $(3: 24$ bis) abiding in the believer and reciprocally the abiding of the believer in the Son $(2: 6,24,28 ; 3: 5,24)$, and I the truth (2 John 2). Mutual abidance is referred to in 4:13, 15, 16; 2 John 9.

24 In Maccabees sons fulfil the conditions of their father and their success proves that they obeyed their father, which implies that they stayed loyal to the covenant of the forefathers, kept the law and its ordinances (Macc 2:19-22, 67, 68).

25 As theology dominates the Fourth Gospel (see Thompson 2001, 1ff), 1 John is also theocentric (cf. Lieu 1986:198; cf. also Malatesta 1978:96): it explores the nature of God's character.

$262: 1,12,14,18,28 ; 3: 1,2,7,10,18 ; 4: 4 ; 5: 2,19,21$.

$272: 9,10 ; 3: 10,12,13,15,17 ; 4: 20,21 ; 5: 16$.

$281: 7 ; 3: 11,14,16,23 ; 4: 7,11,12$.

29 Compare Van der Watt 1999:491-511; Schulz 1987:512-526; and Johnson 1993:7f, 18-19; cf. also Brown 1982:79ff. 
30 Jesus' role and function as paraklhto has to be understood within the framework of the "family court" (family concilium). Such a court served as an organ of discipline that was constituted by the core unit of the family. Normally, the male head of the family conferred with other members before deciding how to react against a member of the family who had trespassed. The noun paraklhto may suggest such a judicial situation. Jesus' advocacy is needed when a "family member" has sinned; he must then approach the Father on their behalf (cf. Van der Watt 1999:500). Plutarch also points out that when conflicts between brothers arise, it is preferable that they be solved internally, between those involved, and with justice as judge (483D, 488B-489B). If necessary, others can be present, as arbitrators or witnesses, but these should be friends which they have in common (483D, 490F-491A).

In the Old Testament the same idea is presented. Members of the family in the wider sense had an obligation to help and to protect one another. In Israel there was an institution which defined the occasions when this obligation called for action; it was the institution of the go' el, from a root which means "to buy back or to redeem", "to lay claim to" - but fundamentally its meaning is "to protect". Thus, the go'el was a protector, a redeemer, a defender of the interests of the individual and of the group. Hence, the functions of the concilium and the go'el help in a certain way to understand the meaning and function of a paraklhto .

31 Within scholarship two distinct and disparate views have developed concerning the message of 1 John. They have arisen as a consequence of two variant perceptions of the purpose of the epistle. The one comprises 'salvation' (5:13, thn zwhn thn aiwnion) and the other 'fellowship' (1:3, koinwnian) (see Derickson 1993:89-105; cf. also Smalley 1984; Kenney 2000a). In fact, they are complementary to one another. Both these themes are mentioned in the prologue of $1 \mathrm{John}$, where the author gives, as we may expect, a synopsis of his principal motifs. In this paper the emphasis falls on the "fellowship" perspective.

32 This is evident from all the references to ton adelfon autou, allhlou", plural personal pronouns, and verbs in the second personal plural.

33 In the New Testament this "mutual sharing" may refer to participation in either material goods, as when Christians in Macedonia and Achaia "raised a common fund" (koinwnian tina poihsasqai) for the poor among the saints in Jerusalem (Rom 15:26); or in spiritual benefits, as when Paul speaks of "sharing" (being sugkoinwno") in the blessings of the gospel (1 Cor 9:23), or enjoying - in the words of "the Grace" - the "fellowship of the Spirit" (2 Cor 13:13; cf. also Rom 15:27). In either sense, the particular "sharing" of Christians, who relate to each other as branches to the true Vine (John 15:1-6), derives from a common faith in Jesus: "we are in him who is true, even in his Son Jesus Christ" (kai esmen en tw alhqinw, en tw uiw autou Ihsou Cristw, 1 John 5:20).

34 The agonising scene at the Cross in the Fourth Gospel (19:25-27), where Jesus entrusts his mother and "the disciple whom he loved" to each other, established the new family, the familia Dei. Whereas the familial imagery had once referred to the family created by Jesus' call, opposed to the natural family of Judaism, the imagery was now used to refer to those who remained faithful to the message that had been passed down from the beginning of the family's existence (Achtemeier, Green \& Thompson 2001:546f).

35 The obligations of the children of God in the family are spelled out in all three Johannine epistles. In each case they contribute to an understanding of the behaviour of these children, which is associated with walking. 1 John 1:6 speaks of the right conduct as walking in the light, whereas 2 John 6 specifies the commandments as the sphere of walking, and 3 John 3 identifies truth as 
the sphere of behaviour (Kenney 2000a:117). See also kaqw" $(2: 6 ; 3: 3,7$; cf. also $3: 23 ; 4: 17)$ in the comparison of the believer's life with the life of Jesus.

36 See 1 John 1:6, 7; 2:3-5, 9-10; 6; 3:16; 4:11; 2 John 6, 9; cf. also 2:29; 3:6, 9-10, 18; 4:7.

37 The verb peripatein occurs five times in $1 \mathrm{John}(1: 6,7 ; 2: 6$ bis and 2:11). In 1:6, 7 en $\mathbf{t w}$ fwti (skotei) peripatwmen is directly linked with koinwnia. This implies that when the tekna qeou walk in the light, they have fellowship with God and one another. When they walk as Jesus walked, they also walk in the light which implies that Jesus walked in the light. In 2 John peripatein occurs thrice to characterise this life in the familia Dei as peripatounta" en alhqeia (v 4) and peripatwmen kata ta" entola" autou (v 6).

38 On the role of the Spirit regarding this cf. John 14:15-19; 15:26-27; 16:5-16; 1 John 2:20, 27; 3:24.

39 The most important ancient rhetorical handbooks that discuss the use of examples (paradeigmata, exempla) are Aristotle's Rhetoric, Quintilian's Institutio Oratoria, and two anonymous treatises, Rhetorica ad Alexandrum and Rhetorica ad Herennium. A lengthy discussion of what each of these rhetoricians says in regard to exempla has already been presented by Cosby (1988:93ff). The question concerning the use of 'examples' as rhetorical devices was whether paradeigmata (exempla) had a probative or an illustrative function.

40 Cf. also Benjamin 1983:65; Cosigny 1989:281-87; Gadamer 1980:3; Holmberg 1977:233; Lake 1986:206f; Murray 1988:286.

41 Du Rand (1979:2) describes the thought process in 1 John as "a spiral, for the development of a theme often brings us back almost to the starting point, almost but not quite, for there is a slight shift which provides a transition to a fresh theme which has apparently been dismissed at an earlier point; and now comes up for consideration from a slightly different angle ... This results in a recapitulation of certain themes."

42 This part of the paper links closely with the tripartite division of this epistle by Tollefson (1999:81-84; cf. also Bruce 1970:29): Prologue 1:1-4; (I) Walking in the light - walking in the darkness (1:5-2:27); (II) Works of righteousness - works of unrighteousness (2:28-4:6); (III) Love brings life - hate brings death (4:7-5:13); and Conclusion (5:14-21).

\section{BIBLIOGRAPHY}

Achtemeier, P. J., Green, J. B. \& Thompson, M. M. 2001. Introducing the new testament: Its literature and theology. Grand Rapids: William B. Eerdmans Publishing Company.

Adams, J. 1983. The familial image in rhetoric. Communication Quarterly 31(1): 56-61.

Apostle, H. G. \& Gerson, L. P. 1982. Aristotle selected works (transl.). Grinnell: The Peripatetic Press.

Benjamin, J. 1983. The Greek concept of dialectics. The Southern Speech Communication Journal 48: 356-67.

Berger, P. L. \& Luckmann, T. 1966. The social construction of reality: A treatise in the sociology of knowledge. Garden City, NY: Doubleday.

Betz, H. D. (ed). 1978. Plutarch's ethical writings and early Christian literature. Leiden: E. J. Brill.

Botha, J. E. 2005. Simple salvation, but not of straw ... Jacobean soteriology, pages 389-408 in Salvation in the new testament: Perspectives on soteriology, edited by J. G. van der Watt. Leiden/Boston: Brill. 
Brettler, M. Z. 1989. God is king: Understanding an Israelite metaphor. Ann Arbor, MI: University Microfilms International.

Brown, R. E. 1982. The epistles of John. New York: Doubleday.

Bruce, F. F. 1970. The epistles of John. London: Pickering \& Inglis Ltd.

Bultmann, R. 1973. The Johannine epistles. Philadelphia: Fortress Press.

Cosby, M. R. 1988. The rhetorical composition and function of Hebrews 11. Macon: Mercer University Press.

Cosigny, S. 1989. Dialectical, rhetorical, and Aristotelian rhetoric. Philosophy and Rhetoric 22(1): 281-87.

Culpepper, R. A. 1995. The general letters: Hebrews, James, 1-2 Peter, Jude, 1-2-3 John. Minneapolis: Fortress Press.

Danker, F. W. (ed). 2000. Greek-English lexicon of the new testament and other early christian literature. $3^{\text {rd }}$ edition. BDAG. Chicago: University of Chicago Press.

Derickson, G. W. 1993. What is the message of 1 John?. BSac 150: 89-105.

De Vaux, R. 1973 (1961). Ancient Israel: Its life and institutions. London: Darton, Longman \& Todd.

Du Rand, J. A. 1979. A discourse analysis of 1 John. Neotestamentica 13: 1-42.

Dixon, S. 1991. The Roman family. Baltimore and London: Croom Helm.

Esler, P. F. 1994. The first Christians in their social worlds: Social-scientific approaches to new testament interpretation). London and New York: Routledge.

Esler, P. F. 1997. Family imagery and Christian identity in Gal 5:13 to 6:10, pages 121-149 in constructing early christian families: Family as social reality and metaphor, edited by $\mathrm{H}$. Moxnes. London and New York: Routledge.

Esler, P. F. 2000. Keeping it in the family: culture, kinship and identity in 1 Thessalonians and Galatians, pages 145-184, in Families and family relations as represented in early Judaisms and early Christianities: Texts and fictions, edited by J. W. van Henten and A. Brenner. Leiden: Deo Publishing.

Gadamer, H. G. 1980. Dialogue and dialectic: Eight hermeneutical studies on Plato. Smith translation. New Haven: Yale University Press.

Haas, C., De Jonge, M. \& Swellengrebel, J. L. 1972. A translater's handbook on the letters of John. London: United Bible Societies.

Holmberg, C. B. 1977. Dialectic rhetoric and rhetorical rhetoric. Philosophy and Rhetoric 10(4): $232-43$.

Johnson, T. F. 1993. 1, 2, and 3 John. Peabody: Hendrickson Publishers.

Joubert, S. \& Van Henten, J. W. 1996. Two a-typical Jewish families in the Greco-Roman period. Neotestamentica 30(1): 121-140.

Kenney, G. C. 2000a. The relation of Christology to ethics in the first epistle of John. New York: University Press of America.

Kenney, G. C. 2000b. Leadership in John: an analysis of the situation and strategy of the Gospel and the Epistles of John. New York: University Press of America.

Klauck, H. -J. 1991a. Der Erste Johannesbrief (EKKNT 23/1). Neukirchen-Vluyn: Neukirchener Verlag. 
Klauck, H. -J. 1991b. Die Johannesbriefe: Erträge der Forschung. Darmstadt: Wissenschaftliche Buchgesellschaft.

Ladd, G. E. 1998. A theology of the new testament. Grand Rapids: William B. Eerdmans.

Lake, R. 1986. The rhetor as dialectician in the last chance for survival. Communication Monographs 53(3): 201-20.

Lakoff, G. \& Johnson, M. 1980. Metaphors we live by. Chicago: Chicago University Press.

Lieu, J. 1986. The second and third epistles of John: History and background. Edinburgh: Clark.

Lieu, J. M. 1991. The theology of the Johannine epistles. Cambridge: Cambridge University Press.

Lassen, E. M. 1997. The Roman family: ideal and metaphor, pages 103-120, in Constructing early Christian families: Family as social reality and metaphor, edited by H. Moxnes. London and New York: Routledge.

Louw, J. P. \& Nida, E. A. 1988. Greek-English lexicon of the new testament based on semantic domains (vol 1). New York: United Bible Societies.

Malatesta, E. 1978. Interiority and covenant. Rome: Biblical Institute Press.

Malherbe, A. J. 1978. The inhospitality of Diotrephes, pages 222-232, in God's Christ and His people (Studies in honour of Nils Alstrup Dahl), edited by J. Jervel \& W. A. Meeks. Oslo: Universitetsforlaget.

Malina, B. J. 1982. The social sciences in biblical interpretation. Int 37: 229-242.

Malina, B. J. 1986. Christian origins and cultural anthropology: Practical models for biblical interpretation. Atlanta: John Knox.

Malina, B. J. 1993. The new testament world. Philadelphia: Fortress.

Malin, B. J. 1996. The social world of Jesus and the gospels. London: Routledge.

Malina, B. J. \& Neyrey, J. H. 1993. First-century personality: Dyadic, not individualistic, pages 6796, in The social world of Luke-acts: Models for interpretation, edited by J. H. Neyrey. Peabody: Hendriksen Publishers.

Moxnes, H. 1997. Constructing early Christian families: Family as social reality and metaphor. London and New York: Routledge.

Murphy, R. F. 1971. The dialectics of social life: Alarm and excursions in anthropological theory. London: Allen and Unwin.

Murray, J. 1988. Disputation, deception, and dialectic: Plato on the true rhetoric (Phaedrus 261-266). Philosophy and Rhetoric 21(4): 279-89.

Neyrey, J. H. (ed). 1993. The social world of Luke-acts: Models for interpretation. Peabody: Hendriksen Publishers.

Oziek, C. \& Balch, D. L. 1997. Families in the new testament world: Households and household churches. Louisville, K. Y.: Westminster/John Knox Press.

Osborn, M. 1967. Archetypal metaphor in rhetoric. Quarterly Journal of Speech 53: 115.

Painter, J. 2002. 1, 2, and 3 John (Sacra Pagina). Collegeville: The Liturgical Press.

Parsons, F. J. 1836. The rhetoric of Aristotle. Cambridge: Whittaker and Co. London.

Plutarch. Moralia. LCL. Helmbold WC (trans.) 1959. [s1]: American Philological Association.

Robbins, V. K. 1996. Exploring the texture of texts: A guide to socio-rhetorical interpretation. Valley Forge: Trinity Press International. 
Rosenblatt, P. C. 1994. Metaphors of family systems theory: Toward new constructions. New York: The Guilford Press.

Rusam, D. 1993. Die Gemeinschaft der Kinder Gottes: Das Motiv der Gotteskindschaft und die Gemeinden der Johanneischen Briefe. Stuttgart: Verlag W. Kohlhammer.

Sandnes, K. O. 1997. Equality within partriarchal structures: Some new testament perspectives on the Christian fellowship as a brother- or sisterhood and a family, pages 150-165 in Constructing early Christian families: Family as social reality and metaphor, edited by H. Moxnes. London and New York: Routledge.

Sandys, J. E (ed). 1909. The rhetoric of Aristotle (Transl. by Claverhouse, R). Cambridge: University Press.

Schäfer, K. 1989. Gemeinde als "Bruderschaft”: Ein Beitrag zum Kirchenverständnis des Paulus. Europeische Hochschulschriften XXIII/333. Bern: Pieter Lang.

Schnackenburg, R. 1967. The moral teaching of the new testament. New York: Herder \& Herder.

Schnackenburg, R. 1984. Die Johannesbriefe (HTHK 13/3). Freiburg: Verlag Herder.

Schnackenburg, R. 1992. The Johannine epistles. New York: Cross Road.

Schroots J. J. F., Birren, J. E. \& Kenyon, G. M. 1991. Metaphors and aging: An overview, in Metaphors of aging in science and the humanities, edited by G. M. Kenyon, J. E. Birren \& J. J. F. Schroots. New York: Springer Publishing Company.

Schulz, S. 1987. Neutestamentliche Ethik. Zürich: Theologischer Verlag.

Smalley, S. S. 1984. 1, 2, 3 John (WBC - vol 51). Dalas: Word Books.

Strecker, G. 1996. The Johannine letters. Minneapolis: Fortress Press.

Thompson, M. M. 2001. The God of the Gospel of John. Grand Rapids: William B. Eerdmans.

Tollefson, K. D. 1999. Certainty within the fellowship: dialectical discourse in 1 John. BTB 29: 79-89.

Van der Merwe, D. G. 2005. Understanding "sin" in the Johannine Epistles. Verbum et Ekklesia 26(2): 543-570.

Van der Watt, J. G. 1992. "Interpreting imagery in John's Gospel: John 10 and 15 as Case Studies," pages 272-282 in Hupomnema: Feesbundel opgedra aan J.P. Louw, edited by Barkhuizen et al. Pretoria: University of Pretoria Press.

Van der Watt, JG. 1999. Ethics in first John: A literary and socioscientific perspective. $C B Q$ 61: 491-511.

Van Henten, J. W. \& Brenner, A. 2000. Families and family relations as represented in early Judaisms and early Christianities: Text and fictions. Leiden: Leo Publishing.

Von Soden, H. F. 1964. Adelfo , pages 144-146 in TDNT, edited by G. Kittel. Grand Rapids: William B. Eerdmans.

Von Wahlde, U. C. 1990. The Johannine Commandments. 1 John and the struggle for the Johannine tradition. New York: Paulist Press.

Watson, D. F. 1989. A rhetorical analysis of 3 John: a study of epistolary rhetoric. CBQ 51: 479-501.

Westcott, B. F. 1982 (1883). The epistles of St John. Johannine studies since Westcott's day by F. F. Bruce. Grand Rapids: William B. Eerdmans. 